\title{
A Novel Thiosemicarbazide-Based Fluorescent Chemosensor for Hypochlorite in Near-Perfect Aqueous Solution and Zebrafish
}

\author{
Minji Lee ${ }^{1}$, Donghwan Choe ${ }^{1} \mathbb{D}$, Soyoung Park ${ }^{1}$, Hyeongjin Kim ${ }^{1}$, Soomin Jeong ${ }^{2}$, Ki-Tae Kim ${ }^{2, *(\mathbb{D})}$ and \\ Cheal Kim 1,*
}

check for updates

Citation: Lee, M.; Choe, D.; Park, S.; Kim, H.; Jeong, S.; Kim, K.-T.; Kim, C. A Novel Thiosemicarbazide-Based Fluorescent Chemosensor for Hypochlorite in Near-Perfect Aqueous Solution and Zebrafish. Chemosensors 2021, 9, 65.

https://doi.org/10.3390/chemosensors 9040065

Received: 29 January 2021

Accepted: 25 March 2021

Published: 28 March 2021

Publisher's Note: MDPI stays neutral with regard to jurisdictional claims in published maps and institutional affiliations.

Copyright: (C) 2021 by the authors. Licensee MDPI, Basel, Switzerland. This article is an open access article distributed under the terms and conditions of the Creative Commons Attribution (CC BY) license (https:// creativecommons.org/licenses/by/ $4.0 /)$.
1 Department of Fine Chemistry, Seoul National University of Science and Technology, Seoul 137-743, Korea; hye6455@seoultech.ac.kr (M.L.); 20510041@seoultech.ac.kr (D.C.); soyoung1119@seoultech.ac.kr (S.P.); adkdk123@seoultech.ac.kr (H.K.)

2 Department of Environmental Engineering, Seoul National University of Science and Technology, Seoul 01187, Korea; soomin_jeong@seoultech.ac.kr

* $\quad$ Correspondence: ktkim@seoultech.ac.kr (K.-T.K.); chealkim@snut.ac.kr (C.K.); Tel.: +82-2-960-6693 (K.-T.K.); $+82-2-972-6640$ (C.K.)

\begin{abstract}
A novel thiosemicarbazide-based fluorescent sensor (AFC) was developed. It was successfully applied to detect hypochlorite $\left(\mathrm{ClO}^{-}\right)$with fluorescence quenching in bis-tris buffer. The limit of detection of AFC for $\mathrm{ClO}^{-}$was analyzed to be $58.7 \mu \mathrm{M}$. Importantly, AFC could be employed as an efficient and practical fluorescent sensor for $\mathrm{ClO}^{-}$in water sample and zebrafish. Moreover, AFC showed a marked selectivity to $\mathrm{ClO}^{-}$over varied competitive analytes with reactive oxygen species. The detection process of AFC to $\mathrm{ClO}^{-}$was illustrated by UV-visible and fluorescent spectroscopy and electrospray ionization-mass spectrometry (ESI-MS).
\end{abstract}

Keywords: thiosemicarbazide; hypochlorite; fluorescent chemosensor; acridine

\section{Introduction}

Concern for the recognition of reactive oxygen species (ROS) has increased because of the significant role of ROS in physiological and pathological processes [1-3]. $\mathrm{ClO}^{-}$, which is one of the significant ROS, is critically important in the human immune system, and has effective antibacterial and anti-inflammatory properties [4-7]. In addition, quantification of $\mathrm{ClO}^{-}$is so important in the environmental system because it is significantly used in industrial fields, for example, as disinfectant and bleaching agent [8-10]. Abnormal amounts of $\mathrm{ClO}^{-}$in organisms cause several diseases, such as inflammation and cardiovascular disease [11-15]. Hence, it is absolutely critical to develop selective and practical sensors for determining the amount of $\mathrm{ClO}^{-}$in life systems [16-20].

Various analytical methods for the detection of $\mathrm{ClO}^{-}$, such as colorimetric analysis, fluorescent detection, electrochemistry, and spectrophotometry, have been developed so far [21-23]. Fluorescence analysis, one of the analytical methods, has the merits of high sensitivity, specificity, fast response time, and manageability [24-27]. A number of fluorescent $\mathrm{ClO}^{-}$sensors have been developed in the past decade, with several functional groups like hydrazide, thioether, thione, thioester, and $\mathrm{C}=\mathrm{N}$ bond [28-33]. Nevertheless, many of them have some problems, such as poor water solubility, complicated synthesis methods, and nonbiological application. Therefore, it is necessary to develop fluorescent chemosensors with good water solubility and biological application.

Acridine and its derivatives are good fluorophores for chemosensors with high fluorescence quantum yield [34,35]. Moreover, amino acridine could readily form conjugated Schiff bases with aldehyde or ketone through the imine formation [36-38]. On the other hand, thiourea moiety is hydrophilic and well known to interact with reactive oxygen species like $\mathrm{ClO}^{-}$[39-43]. Hence, we expected that a compound with thiourea moiety 
linked to amino acridine may be a water-soluble chemosensor capable of detecting ROS like hypochlorite.

Here, we present a distinctly hypochlorite-specific fluorescent chemosensor, AFC, based on acridine moiety. Sensor AFC showed obvious fluorescent quenching and spectral variation with $\mathrm{ClO}^{-}$. In particular, $\mathrm{AFC}$ could monitor $\mathrm{ClO}^{-}$in zebrafish and environmental samples. With ESI-MS (electrospray ionization-mass spectrometry) analysis and ${ }^{1} \mathrm{H}$ NMR titration, the sensing process of $\mathrm{AFC}$ for $\mathrm{ClO}^{-}$was proposed.

\section{Experiments}

\subsection{Materials and Equipment}

All the reagents and solvents used for synthesis and spectroscopic measurements were purchased from Sigma-Aldrich. A Varian spectrometer (Mercury) was used to get ${ }^{13} \mathrm{C}$ NMR $(100 \mathrm{MHz})$ and ${ }^{1} \mathrm{H}$ NMR $(400 \mathrm{MHz})$ spectra. Elemental analysis for $\mathrm{C}, \mathrm{H}, \mathrm{N}$, and $\mathrm{S}$ was carried out by using a Vario Macro/Micro-Cube elemental analyzer. PerkinElmer UV/Visible and fluorescence spectrometers were employed for UV-VIS and fluorescent measurements. A single-quadrupole ACQUITY QDa was employed to get ESI mass data.

\subsection{Synthesis of FHC (2-Formyl-N-(Furan-2-Ylmethyl)Hydrazine-1-Carbothioamide)}

An amount of $2 \mathrm{mmol}$ of furfuryl isothiocyanate was dissolved in $\mathrm{EtOH}(7 \mathrm{~mL})$. Then, $2 \mathrm{mmol}$ of formic hydrazide was added to the solution. The mixture was shaken until a pale-yellow-colored powder precipitated. The pale-yellowish powder was filtered and scrubbed with methanol and ether [44]. Yield, 65\%. ${ }^{1} \mathrm{H}$ NMR in DMSO- $d_{6}: 9.88(\mathrm{~s}, 1 \mathrm{H})$, $9.40(\mathrm{~s}, 1 \mathrm{H}), 7.98(\mathrm{~s}, 1 \mathrm{H}), 7.95(\mathrm{~s}, 1 \mathrm{H}), 7.56(\mathrm{~s}, 1 \mathrm{H}), 6.38(\mathrm{t}, 1 \mathrm{H}), 6.23(\mathrm{~d}, 1 \mathrm{H})$, and $4.66(\mathrm{~s}, 2 \mathrm{H})$.

\subsection{Synthesis of AFC ((E)-2-((Acridin-9-Ylimino)Methyl)-N-(Furan-2-Ylmethyl)Hydrazine- 1-Carbothioamide)}

An amount of $1 \times 10^{-3} \mathrm{~mol}$ of FHC was dissolved in $\mathrm{EtOH}(7 \mathrm{~mL})$. Then, $1 \times 10^{-3}$ mol of 9-aminoacridine (AAD) was dissolved in the solution. The mixture was stirred overnight, until the yellow powder precipitated. The yellow powder filtered was scrubbed with ether. Yield, $48 \% .{ }^{1} \mathrm{H}$ NMR in DMSO- $d_{6}, \delta: 8.45(\mathrm{~s}, 1 \mathrm{H}), 8.40(\mathrm{~d}, 2 \mathrm{H}), 7.80(\mathrm{~d}, 2 \mathrm{H})$, $7.65(\mathrm{~m}, 3 \mathrm{H}), 7.32(\mathrm{t}, 2 \mathrm{H}), 6.45(\mathrm{~m}, 2 \mathrm{H})$, and $5.17(\mathrm{~s}, 2 \mathrm{H}) .{ }^{13} \mathrm{C}$ NMR in DMSO- $d_{6}: \delta=166.0$, $148.3,148.1,143.4,141.8,130.2,128.0,130.2,128.0,123.4,121.7,112.80,110.8,109.4$, and 40.4 ppm. ESI mass: $\mathrm{m} / \mathrm{z}$ calcd for $\left[\mathrm{C}_{20} \mathrm{H}_{17} \mathrm{~N}_{5} \mathrm{OS}+\mathrm{H}^{+}+\mathrm{DMSO}\right]^{+}: 454.14$; found, 454.47 . Elemental analysis: calcd (\%) for $\mathrm{C}_{20} \mathrm{H}_{19} \mathrm{~N}_{5} \mathrm{O}_{2} \mathrm{~S}\left(\mathrm{AFC}+\mathrm{H}_{2} \mathrm{O}\right): \mathrm{C}, 61.05 ; \mathrm{H}, 4.87 ; \mathrm{N}, 17.80 ; \mathrm{S}$, 8.15; found (\%): C, 60.96; H, 4.35; N, 17.44; S, 7.99.

\subsection{General Procedures}

A stock solution of AFC was prepared by dissolving AFC (0.05 mmol) in DMSO $(5.0 \mathrm{~mL})$. An aqueous $\mathrm{NaClO}$ solution $(500 \mu \mathrm{mol}, 11 \%)$ was diluted in distilled water to make a concentrated solution $(100 \mathrm{mM})$. Stock solutions of varied anions and ROS were prepared in bis-tris buffer. Fluorescent and UV-visible data were recorded in a near-perfect aqueous media (10 mM, bis-tris, $\mathrm{pH} 7.0)$.

\subsection{Imaging in Zebrafish}

Under the previous conditions were cultured zebrafish embryos [45]. An amount of $66 \mu \mathrm{L}$ of a stock AFC solution $(15.2 \mathrm{mM})$ was diluted to $20 \mathrm{~mL}$ bis-tris buffer. The zebrafish embryos ( 6 days old) were treated with the diluted AFC $(50 \mu \mathrm{M})$ for $20 \mathrm{~min}$ and then smoothly washed with E2 media to get rid of the excess of AFC. Afterward, the zebrafish were divided into two groups. One was control group and the other group was experimental group. In the experimental group, the zebrafish were further dealt with $50 \mu \mathrm{M}$ of $\mathrm{ClO}^{-}$for $15 \mathrm{~min}$ and scrubbed with E2 media. The zebrafish were narcotized by adding ethyl-3-aminobenzoate methanesulfonate. The fluorescence images of the zebrafish were obtained by a fluorescent microscope. 


\section{Results and Discussion}

Chemosensor AFC was obtained by the imine formation reaction of 9-aminoacridine and FHC (Scheme 1). It was verified by ${ }^{1} \mathrm{H}$ NMR, ${ }^{13} \mathrm{C}$ NMR, and ESI-MS. The detecting process of AFC to $\mathrm{ClO}^{-}$was studied by UV-VIS spectroscopy, fluorescent spectroscopy, and ${ }^{1} \mathrm{H}$ NMR titration.

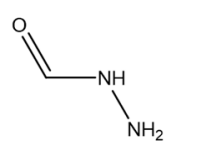

(1)<smiles>S=C=NCc1ccco1</smiles>

$\overrightarrow{\mathrm{EtOH}}$<smiles>O=CNNC(=S)NCc1ccco1</smiles>

FHC<smiles>O=CNNC(=S)NCc1ccc(CCO)o1</smiles><smiles>S=C(NCc1ccco1)NN/C=N/c1c2ccccc2nc2ccccc12</smiles>

Scheme 1. Synthesis of AFC.

\subsection{Spectroscopic Investigations of Chemosensor AFC to $\mathrm{ClO}^{-}$}

We examined the fluorescent responses of AFC to varied anions $\left(\mathrm{Br}^{-}, \mathrm{CN}^{-}, \mathrm{S}^{2-}, \mathrm{I}^{-}\right.$, $\mathrm{SCN}^{-}, \mathrm{OAc}^{-}, \mathrm{ClO}^{-}, \mathrm{F}^{-}, \mathrm{H}_{2} \mathrm{PO}_{4}{ }^{-}, \mathrm{N}_{3}^{-}, \mathrm{BzO}^{-}, \mathrm{NO}_{2}{ }^{-}$, and $\left.\mathrm{Cl}^{-}\right)$and $\mathrm{ROS}$ species $\left(\mathrm{H}_{2} \mathrm{O}_{2}\right.$, $\mathrm{AcOOH}$, and $\mathrm{tBuOOH}$ ) in buffer (Figure 1). Sensor AFC exhibited an intense fluorescence emission at $455 \mathrm{~nm}$ with excitation at $350 \mathrm{~nm}(\Phi=0.8438)$. When 290 equivalents of varied anions were added, respectively, to the AFC solution, only $\mathrm{ClO}^{-}$induced a distinct decrease in fluorescence emission $(\Phi=0.0197)$. By contrast, the other anions did not make substantial changes in fluorescent intensity, and $\mathrm{AcOOH}$ showed some increase in intensity at $455 \mathrm{~nm}$. This result verified that chemosensor AFC could be served as an efficient fluorescent sensor for selectively detecting $\mathrm{ClO}^{-}$.

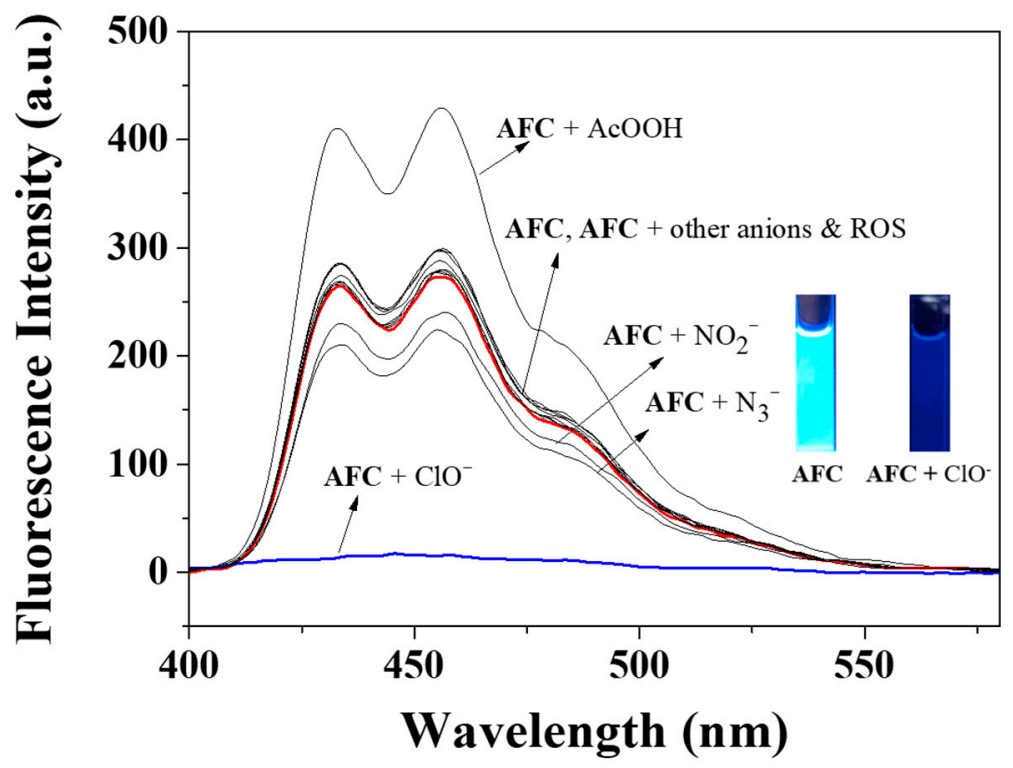

Figure 1. Fluorescent variations of AFC $\left(1 \times 10^{-5} \mathrm{M}\right)$ with various anions (290 equivalents).

Spectroscopic titrations were implemented to investigate the physical responses of $\mathrm{AFC}$ to $\mathrm{ClO}^{-}$(Figure 2). In addition to $\mathrm{ClO}^{-}$, the intensity of the fluorescence emission 
of AFC at $455 \mathrm{~nm}$ gradually decreased, and the detection limit $\left(\mathrm{C}_{\mathrm{DL}}=3 \sigma / \mathrm{k}\right)$ for $\mathrm{ClO}^{-}$ turned out to be $58.7 \mu \mathrm{M}$ (Figure S1). In the same way, UV-VIS titration was carried out (Figure 3). The result showed a consistent increase of absorbance at 320 and $490 \mathrm{~nm}$ and a decrease of absorbance at $400 \mathrm{~nm}$ with an apparent isosbestic point at $420 \mathrm{~nm}$. In addition, the time-dependent UV-VIS change of AFC showed that AFC was stable enough for $1 \mathrm{~h}$ (Figure S2).

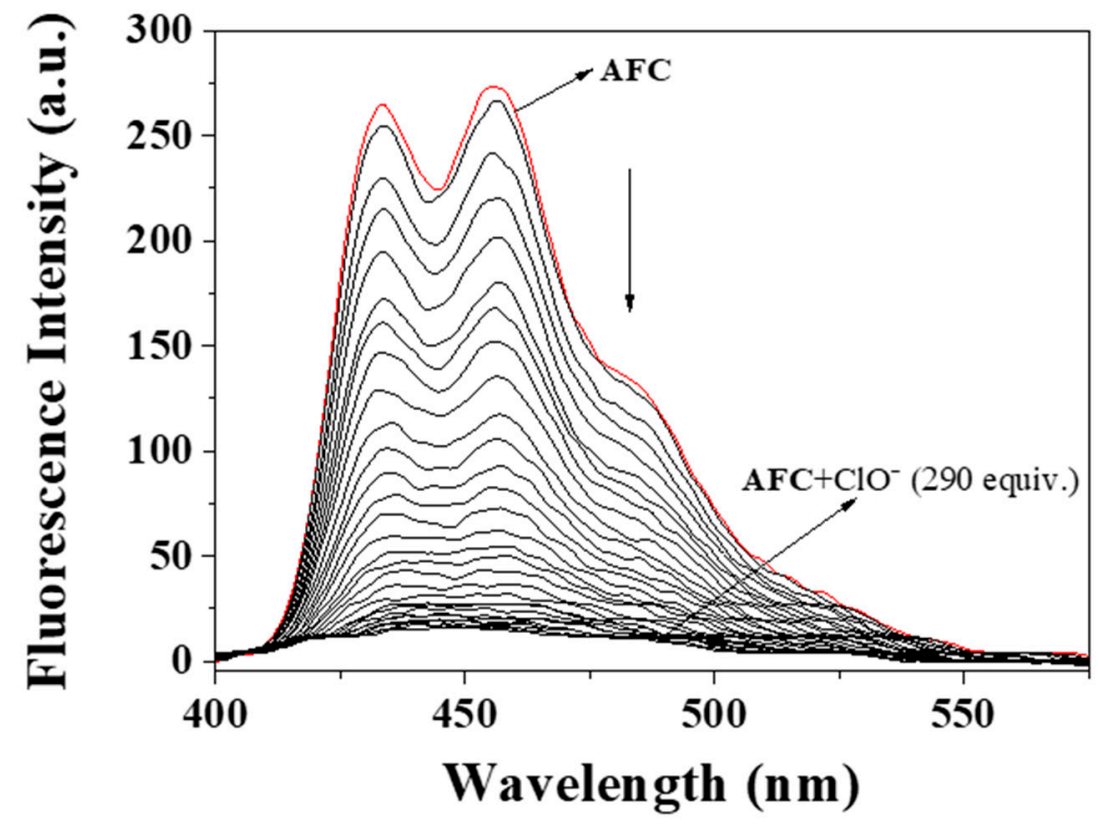

Figure 2. Fluorescent change of AFC $\left(1 \times 10^{-5} \mathrm{M}\right)$ with different amounts of $\mathrm{ClO}^{-}$(from 0 to 290 equivalents).

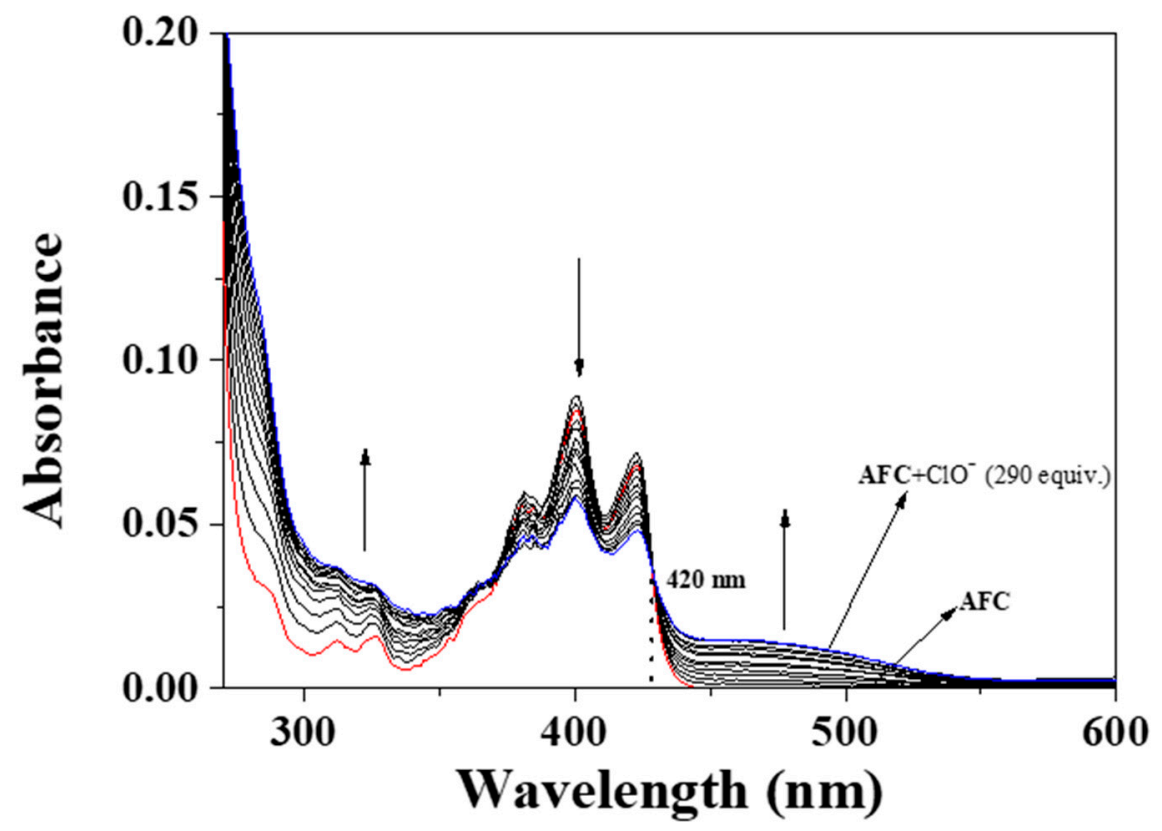

Figure 3. UV-VIS change of probe AFC $\left(1 \times 10^{-5} \mathrm{M}\right)$ with different amounts of $\mathrm{ClO}^{-}$.

The binding process of AFC to $\mathrm{ClO}^{-}$could be demonstrated with the result of the ESI-mass experiment (Figure S3). The peak at $m / z=211.294$ can be assigned as [AAD-O $\left.+\mathrm{H}^{+}\right]^{+}$(calcd, $m / z=211.090$ ). In addition, we can assign the peak at $m / z=232.287$ as 
$\left[\mathrm{FHC}+\mathrm{MeOH}+\mathrm{H}^{+}\right]^{+}(\mathrm{calcd}, m / z=232.080)$. The outcome suggests that the $\mathrm{C}=\mathrm{N}$ bond of AFC would be cleaved by $\mathrm{ClO}^{-}$to produce FHC and AAD. Then, AAD was further oxidized to AAD-O by another $\mathrm{ClO}^{-}$. To get more information on the cleavage of AFC, ${ }^{1} \mathrm{H}$ NMR titration was conducted (Figure 4). Consequently, the imine proton $\left(\mathrm{H}_{6}\right)$ of AFC disappeared due to the cleavage of the imine bond. The amine protons $\left(\mathrm{H}_{5}\right.$ and $\left.\mathrm{H}_{5^{\prime}}\right)$ of AAD-O and the aldehyde proton $\left(\mathrm{H}_{6^{\prime}}\right)$ of FHC appeared.

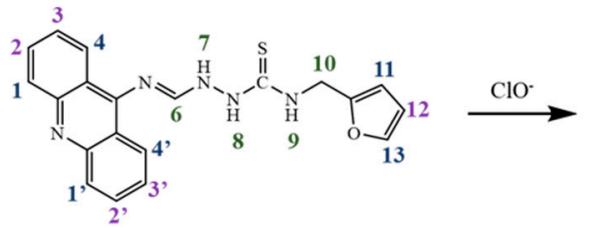

AFC

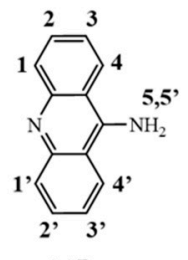

AAD

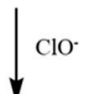

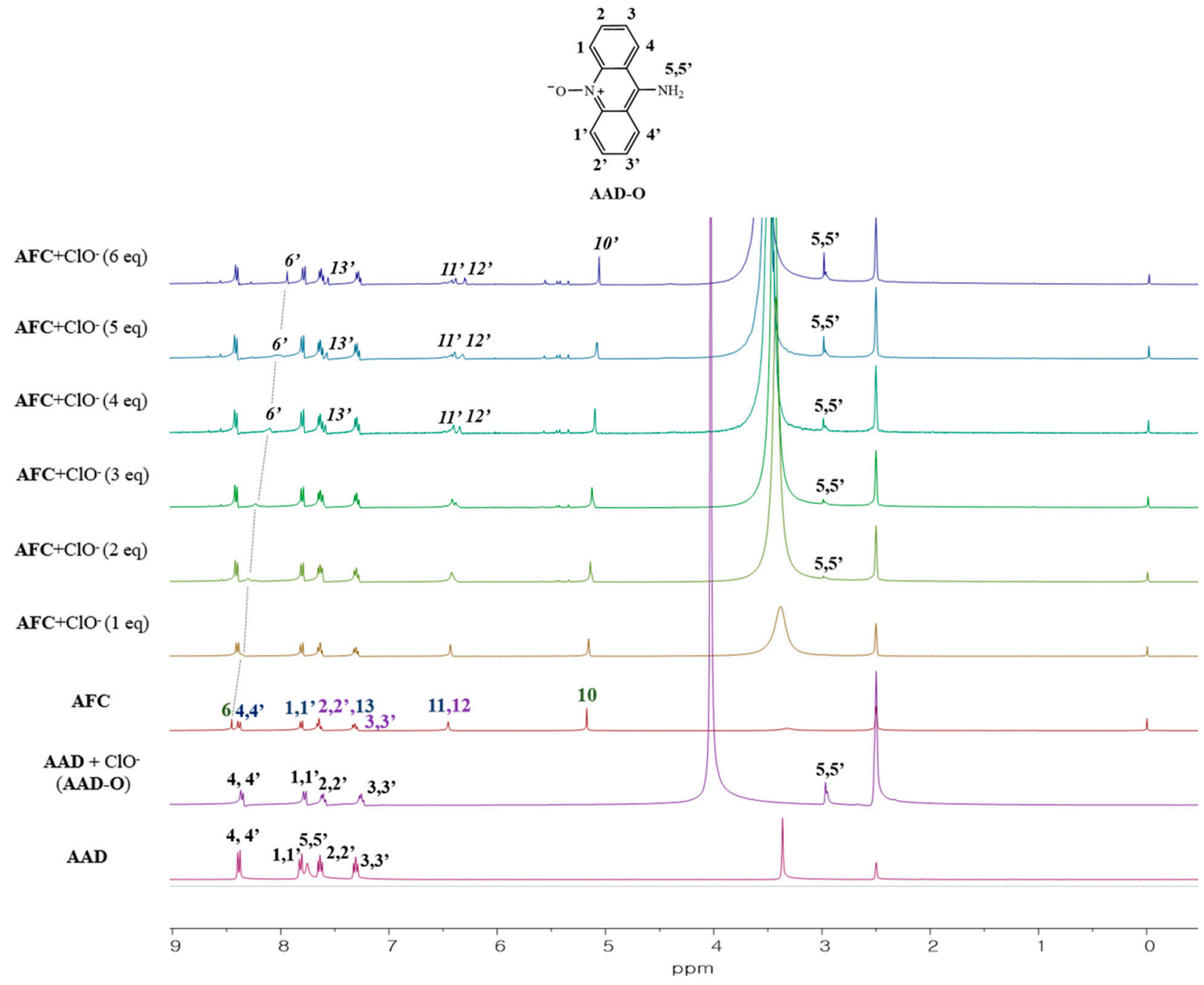

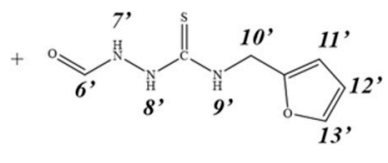

FHC

Figure 4. ${ }^{1} \mathrm{H}$ NMR titration of $\mathrm{AFC}$ with $\mathrm{ClO}^{-}\left(\mathrm{DMSO}_{-} d_{6}\right)$.

To further understand the sensing mechanism, we investigated the fluorescent and UV-VIS changes of AAD and FHC upon the addition of $\mathrm{ClO}^{-}$(290 equivalents). The fluorescent intensity of AAD was substantially decreased by adding $\mathrm{ClO}^{-}$, suggesting the oxidation of AAD into AAD-O (Figure S4). The UV-VIS spectra of AAD showed an 
increase of absorbance at around $490 \mathrm{~nm}$ (Figure S5). On the other hand, FHC with/without $\mathrm{ClO}^{-}$showed no fluorescence intensity and an increase in UV-VIS absorbance at $280 \mathrm{~nm}$ (Figures S6 and S7). Therefore, these observations and the results of the ESI-MS and ${ }^{1} \mathrm{H}$ NMR titration drove us to propose that the $\mathrm{C}=\mathrm{N}$ bond of $\mathrm{AFC}$ was cleaved by $\mathrm{ClO}^{-}$, and then the resultant AAD was further oxidized to AAD-O by another $\mathrm{ClO}^{-}$(Scheme 2).

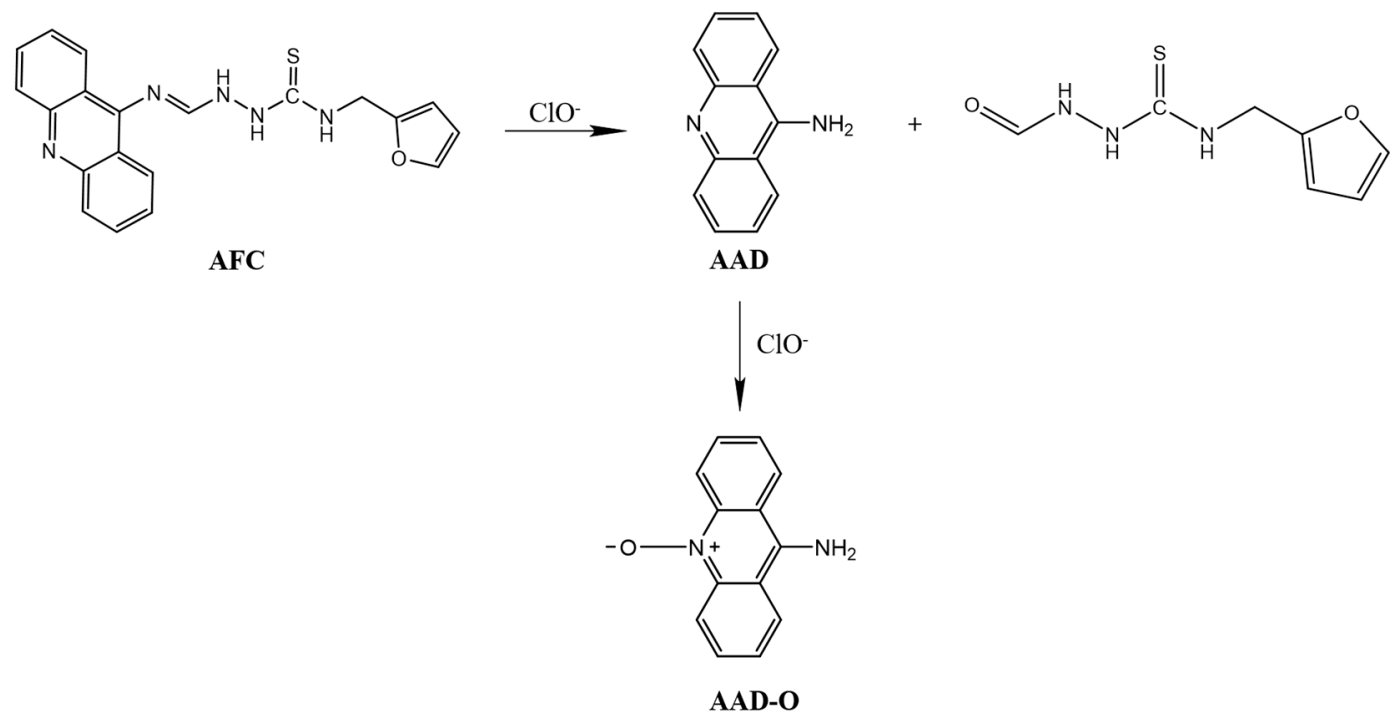

Scheme 2. Sensing process of $\mathrm{AFC}$ by $\mathrm{ClO}^{-}$.

To inspect the capability of $\mathrm{AFC}$ as a $\mathrm{ClO}^{-}$sensor, we conducted a competitive test in the presence of $\mathrm{ClO}^{-}$mixed with other anions of the same equivalents (Figure 5). The result demonstrated that all other analytes did not disturb the detection of $\mathrm{ClO}^{-}$ by AFC. Therefore, sensor AFC could be applied as an efficient chemosensor for $\mathrm{ClO}^{-}$ without the interference of other analytes. Moreover, the $\mathrm{pH}$ condition is critical for cellular behaviors and physiological processes. To evaluate the $\mathrm{pH}$ dependence of AFC, we measured fluorescent intensity in the range of $\mathrm{pH}$ 6-9 (Figure 6). AFC displayed intense fluorescence at $\mathrm{pH} 6-9$, and the addition of $\mathrm{ClO}^{-}$to $\mathrm{AFC}$ induced fluorescence quenching at $\mathrm{pH} 7-9$. These outcomes imply that AFC could successfully detect $\mathrm{ClO}^{-}$at $\mathrm{pH} 7-9$. In addition, fluorescent analysis in the real samples including tap and drinking water was implemented for the practicality of probe AFC. The trustworthy values of recoveries and relative standard deviation (RSD) gave proof of the potential application of AFC to detect $\mathrm{ClO}^{-}$in real samples (Table 1).

Table 1. Analysis of $\mathrm{ClO}^{-\mathrm{a}}$

\begin{tabular}{ccccc}
\hline Sample & $\begin{array}{c}\mathrm{ClO}^{-} \text {Added } \\
(\mu \mathrm{M})\end{array}$ & $\begin{array}{c}\mathbf{C l O}^{-} \text {Found } \\
(\mu \mathbf{M})\end{array}$ & Recovery (\%) & RSD ( $\boldsymbol{n}=\mathbf{3})(\%)$ \\
\hline Drinking water & 0.0 & 0.0 & 99.15 & 0.24 \\
\hline Tap water & $40.0^{\mathrm{b}}$ & 39.7 & \\
\hline & 0.0 & 0.00 & 95.64 & 0.18 \\
\hline
\end{tabular}

a Condition: $[\mathrm{AFC}]=1 \times 10^{-5} \mathrm{M}$ in buffer $(\mathrm{pH} 7.0) .{ }^{\mathrm{b}, \mathrm{c}} 40.0 \mu \mathrm{M}$ of $\mathrm{ClO}^{-}$was artificially added. 


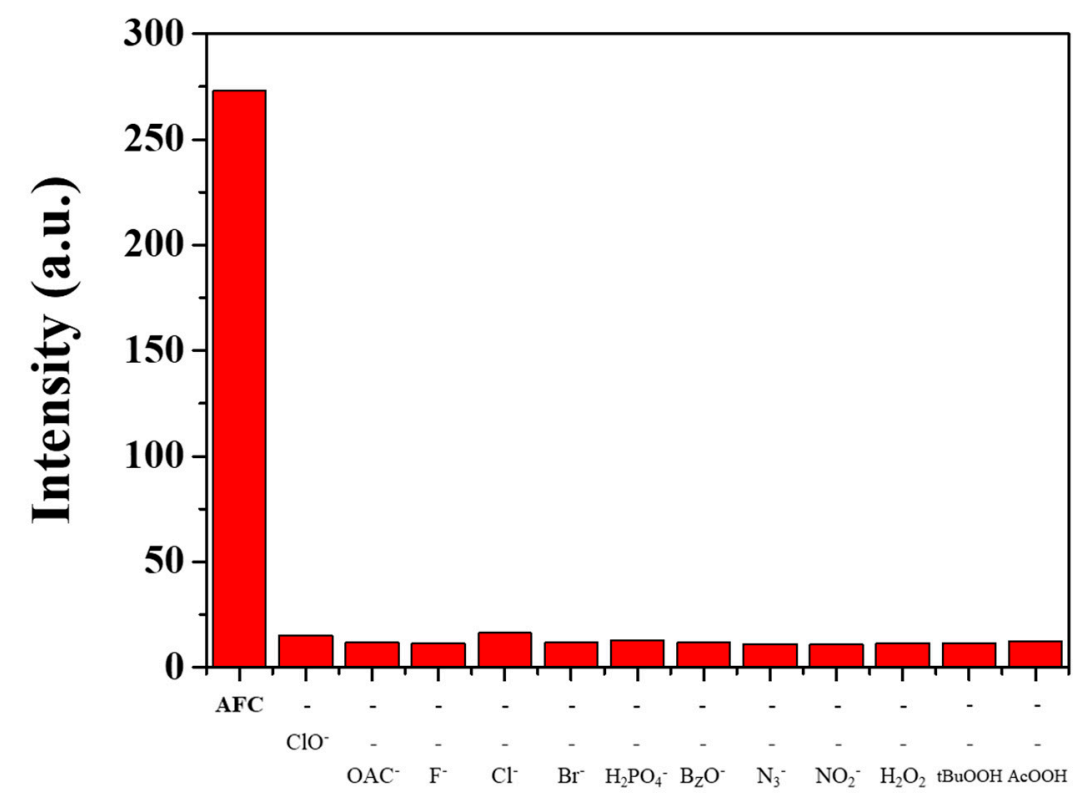

Figure 5. Competitive test $(455 \mathrm{~nm})$ of $\mathrm{AFC}\left(1 \times 10^{-5} \mathrm{M}\right)$ to $\mathrm{ClO}^{-}(290$ equivalents $)$ in the presence of other anions (290 equivalents).

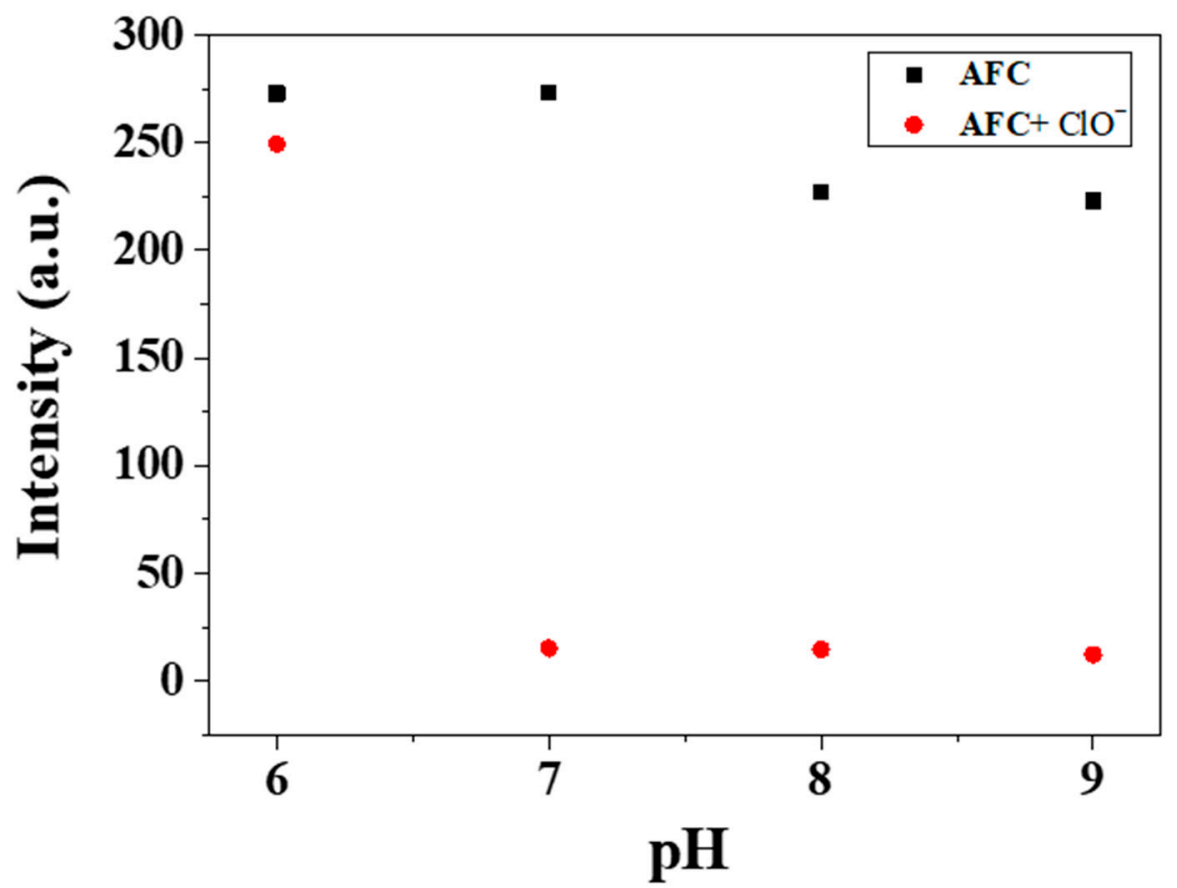

Figure 6. Fluorescence emission (at $455 \mathrm{~nm}$ ) of $\mathrm{AFC}_{\text {with }} \mathrm{ClO}^{-}$at $\mathrm{pH} 6-9$.

\subsection{In Vivo Imaging in Zebrafish}

In order to test the sensing feasibility of the biological application of $\mathrm{AFC}$ to $\mathrm{ClO}^{-}$ fluorescent bioimaging, experiments were conducted with zebrafish (Figure 7). We first incubated zebrafish with AFC $(50 \mu \mathrm{M})$, followed by treatment with $\mathrm{ClO}^{-}(50 \mu \mathrm{M})$. While the zebrafish treated with only probe AFC exhibited a green fluorescence in the swim bladder and eyes, the zebrafish with additional treatment of $\mathrm{ClO}^{-}$showed no fluorescence signal. The bioimaging experiments demonstrated the detecting ability of AFC to trace $\mathrm{ClO}^{-}$in living organisms. Importantly, AFC is the second fluorescent turnoff sensor for $\mathrm{ClO}^{-}$applicable to both real water samples and zebrafish [46-51]. 


\section{Bright field}

\section{Green channel}

\section{Overlay}

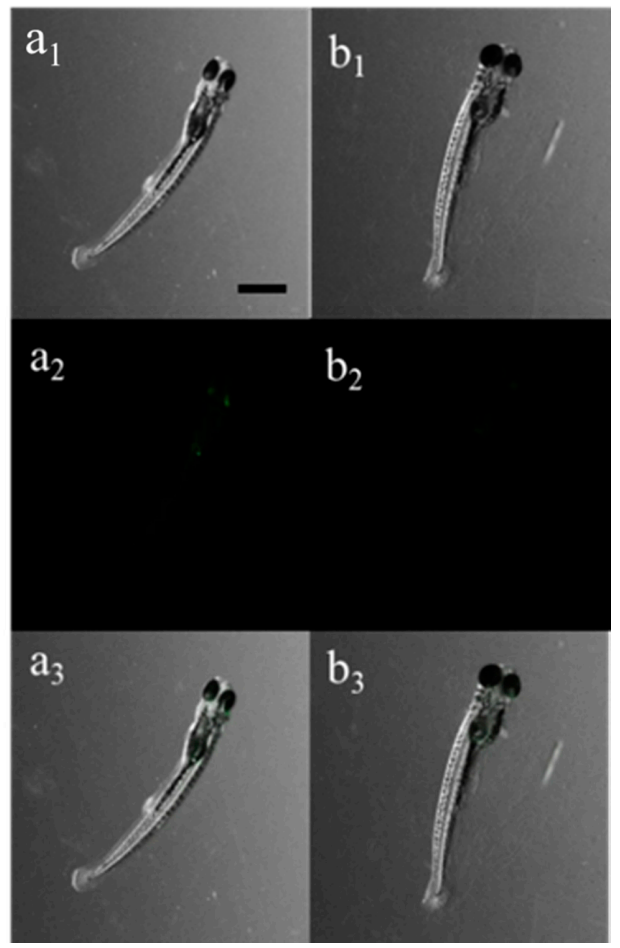

Figure 7. Fluorescence images of zebrafish ( 6 days old) treated with AFC followed by the addition of $\mathrm{ClO}^{-} .\left(\mathbf{a}_{1}-\mathbf{a}_{3}\right):$ AFC only; $\left(\mathbf{b}_{1}-\mathbf{b}_{3}\right):$ AFC with $5 \times 10^{-5} \mathrm{M} \mathrm{ClO}^{-}$. [AFC] $=5 \times 10^{-5} \mathrm{M}$.

\section{Conclusions}

A novel thiosemicarbazide-based chemosensor AFC for detecting $\mathrm{ClO}^{-}$was synthesized from the reaction of aminoacridine and a new aldehyde group synthesized from formic hydrazide. Probe AFC selectively recognized $\mathrm{ClO}^{-}$over other anions including ROS in aqueous solution. With $\mathrm{ClO}^{-}$, probe AFC showed remarkable fluorescence quenching. The limit of detection of $\mathbf{A F C}$ for $\mathrm{ClO}^{-}$was calculated to be $58.7 \mu \mathrm{M}$. Additionally, probe AFC could be applicable for quantitative analysis in real water samples and zebrafish. Importantly, AFC is the second fluorescent turnoff sensor for $\mathrm{ClO}^{-}$applicable to both real water samples and zebrafish. The dependable results in this study shows that AFC could be used as an efficient chemosensor for detecting $\mathrm{ClO}^{-}$in aqueous solution and small organisms by a fluorescent quenching method.

Supplementary Materials: The following are available online at https://www.mdpi.com/article/ 10.3390/chemosensors9040065/s1. Table S1: Fluorescent turnoff chemosensors for recognizing hypochlorite in aqueous solutions. Figure S1: Determination of the detection limit of $\mathbf{A F C}$ for $\mathrm{ClO}^{-}$ based on the change of intensity at $455 \mathrm{~nm}$. Figure S2: The time-dependent UV-VIS change (400 nm) of AFC with/without $\mathrm{ClO}^{-}$. Figure S3: Positive-ion ESI mass spectrum of AFC upon the addition of $\mathrm{NaClO}$. Figure S4: Fluorescent change of AAD with/without $\mathrm{ClO}^{-}$. Figure S5: UV-VIS change of AAD with/without $\mathrm{ClO}^{-}$Figure S6: Fluorescent change of $\mathbf{F H C}$ with/without $\mathrm{ClO}^{-}$. Figure S7: UV-VIS change of FHC with/without $\mathrm{ClO}^{-}$.

Author Contributions: Conceptualization, M.L. and C.K.; formal analysis, M.L.; investigation, M.L., D.C., H.K. and S.J.; data curation, M.L., S.P. and D.C.; writing—original draft preparation, M.L., D.C. and S.P.; writing - review and editing, M.L. and C.K.; supervision, C.K. and K.-T.K.; funding acquisition, C.K. and K.-T.K. All authors have read and agreed to the published version of the manuscript.

Funding: We acknowledge the Korea Environmental Industry and Technology Institute (KEITI) through "The Chemical Accident Prevention Technology Development Project", funded by the Korean Ministry of Environment (MOE) (No. 2016001970001). 
Institutional Review Board Statement: The maintenance of zebrafish was approved by the Institutional Animal Care and Use Committees at the Seoul National University of Science and Technology. Ethical review and approval were waived for this study because early-life stages of zebrafish $(<120 \mathrm{hpf})$ are not protected according to the European Union (EU) Directive 2010/63/EU.

Informed Consent Statement: Not applicable.

Conflicts of Interest: The authors declare no conflict of interest.

\section{References}

1. Ji, R.; Qin, K.; Liu, A.; Zhu, Y.; Ge, Y. A simple and fast-response fluorescent probe for hypochlorite in living cells. Tetrahedron Lett. 2018, 59, 2372-2375. [CrossRef]

2. Jiang, Y.; Zheng, G.; Duan, Q.; Yang, L.; Zhang, J.; Zhang, H.; He, J.; Sun, H.; Ho, D. Ultra-sensitive fluorescent probes for hypochlorite acid detection and exogenous/endogenous imaging of living cells. Chem. Commun. 2018, 54, 7967-7970. [CrossRef] [PubMed]

3. Yun, D.; Chae, J.B.; Kim, C. An imine-based colorimetric chemodosimeter for the detection of hypochlorite $\left(\mathrm{ClO}^{-}\right)$in aqueous media: Its application in test strips and real water samples. J. Chem. Sci. 2019, 131, 1-8. [CrossRef]

4. Lou, X.; Zhang, Y.; Qin, J.; Li, Z. Colorimetric hypochlorite detection using an azobenzene acid in pure aqueous solutions and real application in tap water. Sens. Actuators B Chem. 2012, 161, 229-234. [CrossRef]

5. Shen, S.L.; Zhang, X.F.; Ge, Y.Q.; Zhu, Y.; Cao, X.Q. A mitochondria-targeting ratiometric fluorescent probe for the detection of hypochlorite based on the FRET strategy. RSC Adv. 2017, 7, 55296-55300. [CrossRef]

6. Xu, X.; Qian, Y. A novel (3,6-di-tert-butylcarbazol-9-yl) triphenylamine-BODIPY-tricyanofuran conjugated dye: Synthesis and rapid naked-eye detection of hypochlorite. New J. Chem. 2017, 41, 9607-9612. [CrossRef]

7. Yi, S.; Lu, Z.; Lin, Y.; Wang, J.; Qiao, Z.; Shen, R.; Zhang, J.; Hou, L. A novel mitochondria-targeted phosphorescence probe for hypochlorite ions detection in living cells. Talanta 2020, 209, 120516. [CrossRef] [PubMed]

8. Lee, S.C.; Kim, C. Naphthalimide-based probe for the detection of hypochlorite in a near-perfect aqueous solution. Anal. Sci. 2019, 35, 1189-1193. [CrossRef]

9. Goswami, S.; Paul, S.; Manna, A. Carbazole based hemicyanine dye for both "naked eye" and 'NIR' fluorescence detection of $\mathrm{CN}^{-}$in aqueous solution: From molecules to low cost devices (TLC plate sticks). Dalton Trans. 2013, 42, 10682-10686. [CrossRef]

10. Lee, S.C.; Kim, C. Naphthol-naphthalimide based 'turn-on' fluorescent sensor for $\mathrm{ClO}^{-}$in aqueous media and test kit. Inorg. Chem. Commun. 2019, 108, 107545. [CrossRef]

11. Sasikumar, T.; Ilanchelian, M. Colorimetric detection of hypochlorite based on the morphological changes of silver nanoprisms to spherical nanoparticles. Anal. Methods 2017, 9, 3151-3158. [CrossRef]

12. Chen, W.C.; Venkatesan, P.; Wu, S.P. A highly selective turn-on fluorescent probe for hypochlorous acid based on hypochlorous acid-induced oxidative intramolecular cyclization of boron dipyrromethene-hydrazone. Anal. Chim. Acta 2015, 882, 68-75. [CrossRef]

13. Duan, R.; Li, C.; Liu, S.; Liu, Z.; Li, Y.; Zhu, J.; Hu, X. A selective fluorescence quenching method for the determination of trace hypochlorite in water samples with nile blue A. J. Taiwan Inst. Chem. Eng. 2015, 50, 43-48. [CrossRef]

14. Lin, X.; Qin, W.; Chen, Y.; Bao, L.; Li, N.; Wang, S.; Liu, K.; Kong, F.; Yi, T. Construction of a multi-signal near-infrared fluorescent probe for sensing of hypochlorite concentration fluctuation in living animals. Sens. Actuators B Chem. 2020, 324. [CrossRef]

15. Zhang, Y.M.; Fang, H.; Zhu, W.; He, J.X.; Yao, H.; Wei, T.B.; Lin, Q.; Qu, W.J. Ratiometric fluorescent sensor based oxazolophenazine derivatives for detect hypochlorite via oxidation reaction and its application in environmental samples. Dyes Pigm. 2020, 172, 107765. [CrossRef]

16. Chang, C.; Wang, F.; Qiang, J.; Zhang, Z.; Chen, Y.; Zhang, W.; Wang, Y.; Chen, X. Benzothiazole-based fluorescent sensor for hypochlorite detection and its application for biological imaging. Sens. Actuators B Chem. 2017, 243, 22-28. [CrossRef]

17. Starzak, K.; Matwijczuk, A.; Creaven, B.; Matwijczuk, A.; Wybraniec, S.; Karcz, D. Fluorescence quenching-based mechanism for determination of hypochlorite by coumarin-derived sensors. Int. J. Mol. Sci. 2019, 20, 281. [CrossRef] [PubMed]

18. Wang, W.; Ning, J.Y.; Liu, J.T.; Miao, J.Y.; Zhao, B.X. A mitochondria-targeted ratiometric fluorescence sensor for the detection of hypochlorite in living cells. Dyes Pigm. 2019, 171, 107708. [CrossRef]

19. Naha, S.; Varalakshmi, A.; Velmathi, S. Nanomolar colorimetric hypochlorite sensor in water. Spectrochim. Acta Part A Mol. Biomol. Spectrosc. 2019, 220, 117123. [CrossRef]

20. Hwang, S.M.; Yun, D.; Kim, C. An Imidazo[1,5- $\alpha$ Pyridine-Based Fluorometric Chemodosimeter for the Highly Selective Detection of Hypochlorite in Aqueous Media. J. Fluoresc. 2019, 29, 451-459. [CrossRef]

21. Zhang, P.; Wang, H.; Hong, Y.; Yu, M.; Zeng, R.; Long, Y.; Chen, J. Selective visualization of endogenous hypochlorous acid in zebrafish during lipopolysaccharide-induced acute liver injury using a polymer micelles-based ratiometric fluorescent probe. Biosens. Bioelectron. 2018, 99, 318-324. [CrossRef] [PubMed]

22. Li, J.; Yin, C.; Liu, T.; Wen, Y.; Huo, F. A new mechanism-based fluorescent probe for the detection of $\mathrm{ClO}^{-}$by $\mathrm{UV}_{-\mathrm{vis}}$ and fluorescent spectra and its applications. Sens. Actuators B Chem. 2017, 252, 1112-1117. [CrossRef] 
23. Dong, X.; Zhang, G.; Shi, J.; Wang, Y.; Wang, M.; Peng, Q.; Zhang, D. A highly selective fluorescence turn-on detection of $\mathrm{ClO}^{-}$with 1-methyl-1,2-dihydropyridine-2-thione unit modified tetraphenylethylene. Chem. Commun. 2017, 53, 11654-11657. [CrossRef] [PubMed]

24. Hwang, S.M.; Kim, A.; Kim, C. A simple hydrazine-based probe bearing anthracene moiety for the highly selective detection of hypochlorite. Inorg. Chem. Commun. 2019, 101, 1-5. [CrossRef]

25. Jeong, H.Y.; Lee, S.Y.; Kim, C. Furan and Julolidine-Based "Turn-on" Fluorescence Chemosensor for Detection of $\mathrm{F}^{-}$in a Near-Perfect Aqueous Solution. J. Fluoresc. 2017, 27, 1457-1466. [CrossRef]

26. Yang, Q.; Zhong, X.; Chen, Y.; Yang, J.; Jin, C.; Jiang, Y. A mitochondria-targeted fluorescent probe for hypochlorite sensing and its application in bioimaging. Analyst 2020, 145, 3100-3105. [CrossRef]

27. Feng, A.; Liu, P.; Liang, Q.; Zhang, X.; Huang, L.; Jia, Y.; Xie, M.; Yan, Q.; Li, C.; Wang, S. A new carbazole-based colormetric and ratiometric fluorescent probe for hypochlorite sensing in living cells and zebrafishes. Dyes Pigm. 2020, 180, 108492. [CrossRef]

28. Ma, Z.; Chen, X.; Wang, C.; Lv, Q. A novel ratiometric fluorescence probe for hypochlorite detection and its application in cell imaging. J. Mol. Struct. 2020, 1221, 128812. [CrossRef]

29. Ning, Y.; Cui, J.; Lu, Y.; Wang, X.; Xiao, C.; Wu, S.; Li, J.; Zhang, Y. De novo design and synthesis of a novel colorimetric fluorescent probe based on naphthalenone scaffold for selective detection of hypochlorite and its application in living cells. Sens. Actuators B Chem. 2018, 269, 322-330. [CrossRef]

30. Zhou, J.; Li, L.; Shi, W.; Gao, X.; Li, X.; Ma, H. HOCl can appear in the mitochondria of macrophages during bacterial infection as revealed by a sensitive mitochondrial-targeting fluorescent probe. Chem. Sci. 2015, 6, 4884-4888. [CrossRef]

31. Dai, Y.; Xu, K.; Li, Q.; Wang, C.; Liu, X.; Wang, P. Acridine-based complex as amino acid anion fluorescent sensor in aqueous solution. Spectrochim. Acta Part A Mol. Biomol. Spectrosc. 2016, 157, 1-5. [CrossRef] [PubMed]

32. Jin, X.; Jia, Y.; Chen, W.; Chui, P.; Yang, Z. A reaction-based fluorescent probe for rapid detection of hypochlorite in tap water, serum, and living cells. Sens. Actuators B Chem. 2016, 232, 300-305. [CrossRef]

33. Wang, B.; Chen, D.; Kambam, S.; Wang, F.; Wang, Y.; Zhang, W.; Yin, J.; Chen, H.; Chen, X. A highly specific fluorescent probe for hypochlorite based on fluorescein derivative and its endogenous imaging in living cells. Dyes Pigm. 2015, 120, 22-29. [CrossRef]

34. Wang, C.; Wang, P.; Liu, X.; Fu, J.; Xue, K.; Xu, K. Novel enantioselective fluorescent sensors for tartrate anion based on acridinezswsxa. Luminescence 2017, 32, 1313-1318. [CrossRef] [PubMed]

35. Chemate, S.; Erande, Y.; Mohbiya, D.; Sekar, N. Acridine derivative as a "turn on" probe for selective detection of picric acid: Via PET deterrence. RSC Adv. 2016, 6, 84319-84325. [CrossRef]

36. Kim, M.S.; Lee, S.Y.; Jung, J.M.; Kim, C. A new Schiff-base chemosensor for selective detection of $\mathrm{Cu}^{2+}$ and $\mathrm{Co}^{2+}$ and its copper complex for colorimetric sensing of $\mathrm{S}^{2-}$ in aqueous solution. Photochem. Photobiol. Sci. 2017, 16, 1677-1689. [CrossRef] [PubMed]

37. Bhattacharyya, A.; Ghosh, S.; Makhal, S.C.; Guchhait, N. Hydrazine bridged coumarin-pyrimidine conjugate as a highly selective and sensitive $\mathrm{Zn}^{2+}$ sensor: Spectroscopic unraveling of sensing mechanism with practical application. Spectrochim. Acta Part A Mol. Biomol. Spectrosc. 2017, 183, 306-311. [CrossRef]

38. Ashraf, A.; Khizar, M.; Islam, M.; Hameed, A.; Tarique Moin, S.; Yaqub, M.; Rauf, W.; Moazzam Naseer, M.; Tayyeb Ahsan, M.; Shafiq, Z.; et al. Synthesis of sensitive novel dual Signaling pyridopyrimidine-based fluorescent "turn off" chemosensors for anions determination. Meas. J. Int. Meas. Confed. 2019, 151, 107267. [CrossRef]

39. Swamy, K.M.K.; Eom, S.; Liu, Y.; Kim, G.; Lee, D.; Yoon, J. Rhodamine derivatives bearing thiourea groups serve as fluorescent probes for selective detection of ATP in mitochondria and lysosomes. Sens. Actuators B Chem. 2019, 281, 350-358. [CrossRef]

40. So, H.; Lee, M.; Kim, C. A Unique Thiosemicarbazide-Based Colorimetric Chemosensor for Fe ${ }^{2+}$ in Pure Aqueous Solution with the Lowest Detection Limit. ChemistrySelect 2020, 5, 10521-10525. [CrossRef]

41. Shen, B.X.; Qian, Y.; Qi, Z.Q.; Lu, C.G.; Sun, Q.; Xia, X.; Cui, Y.P. Near-infrared BODIPY-based two-photon $\mathrm{ClO}^{-}$probe based on thiosemicarbazide desulfurization reaction: Naked-eye detection and mitochondrial imaging. J. Mater. Chem. B 2017, 5, 5854-5861. [CrossRef]

42. Zeng, Y.N.; Zheng, H.Q.; He, X.H.; Cao, G.J.; Wang, B.; Wu, K.; Lin, Z.J. Dual-emissive metal-organic framework: A novel turn-on and ratiometric fluorescent sensor for highly efficient and specific detection of hypochlorite. Dalton Trans. 2020, 49, 9680-9687. [CrossRef] [PubMed]

43. Li, C.; Yin, P.; Li, T.; Wei, T.; Hu, T.; Chen, J.; Qin, X.; Niu, Q. Rapid and sensitive detection of hypochlorite in $100 \%$ aqueous solution using a bithiophene-based fluorescent sensor: Application to water analysis and live-cell imaging. J. Mol. Liq. 2020, 320, 114396. [CrossRef]

44. Cai, W.; Wu, J.; Liu, W.; Xie, Y.; Liu, Y.; Zhang, S.; Xu, W.; Tang, L.; Wang, J.; Zhao, G. Systematic structure-activity relationship (SAR) exploration of diarylmethane backbone and discovery of a highly potent novel uric acid transporter 1 (URAT1) inhibitor. Molecules 2018, 23, 252. [CrossRef] [PubMed]

45. Kim, M.S.; Yun, D.; Chae, J.B.; So, H.; Lee, H.; Kim, K.; Kim, M.; Lim, M.H.; Kim, C. A Novel Thiophene-Based Fluorescent Chemosensor for the Detection of $\mathrm{Zn}^{2+}$ and $\mathrm{CN}^{-}$: Imaging Applications in Live Cells and Zebrafish. Sensors 2019, 19, 5458. [CrossRef] [PubMed]

46. Chen, H.; He, X.; Yu, Y.; Qian, Y.; Shen, J.; Zhao, S. Execution of aggregation-induced emission as nano-sensors for hypochlorite detection and application for bioimaging in living cells and zebrafish. Talanta 2020, 214, 120842. [CrossRef]

47. So, H.; Lee, H.; Lee, G.D.; Kim, M.; Lim, M.H.; Kim, K.T.; Kim, C. A thiourea-based fluorescent chemosensor for bioimaging hypochlorite. J. Ind. Eng. Chem. 2020, 89, 436-441. [CrossRef] 
48. Zhu, Y.; Ma, Y.; Liu, Y.; Liu, Z.; Ma, S.; Xing, M.; Cao, D.; Lin, W. Fluorescence response of a fluorescein derivative for hypochlorite ion and its application for biological imaging in wounded zebrafish and living mice. Sens. Actuators B Chem. 2021, 327,128848 [CrossRef]

49. Zhang, Y.; Zuo, Y.; Yang, T.; Gou, Z.; Wang, X.; Lin, W. Novel fluorescent probe with a bridged Si-O-Si bond for the reversible detection of hypochlorous acid and biothiol amino acids in live cells and zebrafish. Analyst 2019, 144, 5075-5080. [CrossRef] [PubMed]

50. Niu, H.; Chen, K.; Xu, J.; Zhu, X.; Cao, W.; Wang, Z.; Ye, Y.; Zhao, Y. Mitochondria-targeted fluorescent probes for oxidative stress imaging. Sens. Actuators B Chem. 2019, 299, 126938. [CrossRef]

51. Lee, S.C.; Park, S.; So, H.; Lee, G.; Kim, K.T.; Kim, C. An acridine-based fluorescent sensor for monitoring clo ${ }^{-}$in water samples and zebrafish. Sensors 2020, 20, 4764. [CrossRef] [PubMed] 